\title{
Preliminary Analysis of Middle Holocene Lake-Level Change of Ancestral Lake Michigan, Wentworth Woods, Cook County, Illinois
}

\author{
Todd A. Thompson ${ }^{1}$, Erin P. Argyilan², Henry M. Loope ${ }^{1}$, John W. Johnston³ ${ }^{3}$ and Kenneth Lepper ${ }^{4}$ \\ ${ }^{1}$ Indiana Geological and Water Survey, Indiana University, Bloomington, Indiana \\ ${ }^{2}$ Department of Geosciences, Indiana University Northwest, Gary, Indiana \\ ${ }^{3}$ Department of Earth and Environmental Sciences, University of Waterloo, Waterloo, Ontario, Canada \\ ${ }^{4}$ Optical Dating and Dosimetry Lab, North Dakota State University, Fargo, North Dakota
}

E-mail: tthomps@indiana.edu

Received 03/29/2019

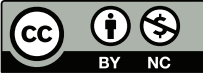

Accepted for publication 06/28/2019

Published 08/08/2019

Suggested citation: Thompson, T. A., Argyilan, E. P., Loope, H. M., Johnston, J. W., and Lepper, Kenneth, 2019, Preliminary analysis of Middle Holocene lake-level change of ancestral Lake Michigan, Wentworth Woods, Cook County, Illinois: Indiana Geological and Water Survey, Indiana Journal of Earth Sciences, v. 1. DOI 10.14434/ijes.vli0.27011

\begin{abstract}
Study of past lake-level change and isostasy in the upper Great Lakes demonstrates the need to reconstruct relative lake-level history at each outlet during the Nipissing phase of ancestral Lakes Huron, Michigan, and Superior. Although elevation and age data exist for the Port Huron/Sarnia and Sault outlets of Lake Huron and Lake Superior, respectively, no paleohydrograph has been created for southern Lake Michigan near the Chicago outlet. The Wentworth Woods area of the Cook County Forest Preserve, Illinois, contains more than 30 beach ridges that formed during the rise and fall from the peak elevation of the Nipissing phase. These relict shorelines were vibracored to recover basal foreshore sediments that can be used as a proxy for lake-level elevation at the time of individual shoreline formation. In addition, we collected sand samples from soil pits and vibracores for optically stimulated luminescence age determinations. This preliminary paper addresses the sedimentological data used to determine the elevation of the conjoined upper Great Lakes when each beach ridge formed. The age data will be presented in future papers.
\end{abstract}

\section{INTRODUCTION}

The Nipissing phase of ancestral Lake Michigan $(6,100$ to 4,500 years ago) was the last pre-modern high phase of the lake, peaking at an elevation of approximately $6 \mathrm{~m}$ above current lake level 4,500 years ago (peak Nipissing phase elevation) (Thompson and others, 2011). At that time, Lakes Michigan, Huron, and Superior were confluent as a single ancestral lake, and shorelines formed contemporaneously along the coastlines of all three of the upper Great Lakes. Outflow during the Nipissing phase was originally northeastward through the North Bay outlet at the east end of present-day Lake Nipissing in Ontario and then shifted southward to discharge through the Port Huron outlet at the southern end of Lake Huron and also through the Chicago outlet at the southwestern margin of Lake Michigan. Subsequent lake-level fall and warping of the basin by ongoing glacial isostatic adjustments (GIA) have abandoned the Nipissing shoreline and altered associated strandplain elevations throughout the upper Great Lakes. Because the Nipissing phase sequence of shorelines formed during a relatively narrow length of 
time and, given that the distinct geomorphology allows us to trace the shoreline occurrence throughout much of the upper Great Lakes, the peak Nipissing is the only relict shoreline that can be used to reconstruct a basinwide lake-level elevation for the entire upper Great Lakes. A single elevational surface established from the current elevations of basal foreshore sediments deposited during the peak Nipissing phase allows us to reconstruct the average rates of glacial isostatic adjustment over the past 45 centuries. Two recent studies addressed the need for the study of the Nipissing shoreline (Thompson and others, 2011, 2014). Of particular interest is the elevation of the peak Nipissing phase at the three outlets of the ancestral upper Great Lakes. Thompson and others (2014) estimated the elevation of the peak Nipissing from Thompson and Baedke (1997) data, but they suggested that a study be conducted that collects basal foreshore data in northwestern Indiana or northeastern Illinois adjacent to Lake Michigan.

The Wentworth Woods area of the Cook County Forest Preserve along Michigan City Road and immediately west of the Illinois-Indiana state boundary contains approximately 30 beach ridges that record the elevation and age of ancestral Lake Michigan during the rise to, and the fall from, the peak Nipissing phase (fig. 1). This area is one of the last remaining undisturbed sites that contains Nipissing shoreline deposits along the southwestern shore of Lake Michigan and is close to the Sag Channel of the Chicago outlet. Wentworth Woods was studied to construct a paleohydrograph during the rise to, and the fall from, the maximum elevation of the Nipissing phase of ancestral Lake Michigan. This preliminary paper addresses the sedimentological data collected during the spring of 2018.

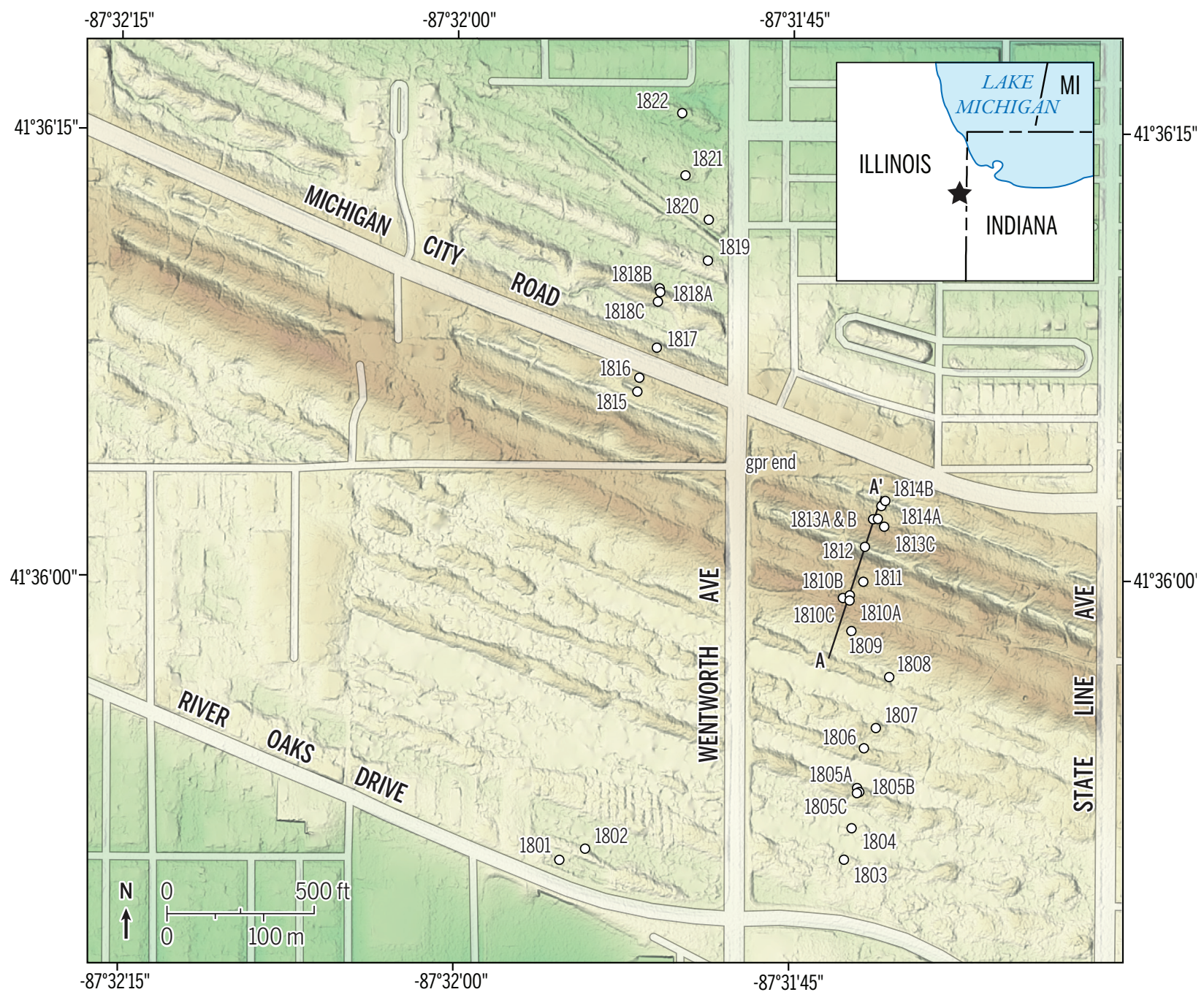

Figure 1. Colored hillshade lidar-derived topographic map of the eastern Wentworth Woods area, showing labeled vibracore locations collected on and at the toeslope of beach ridges and the location of the ground penetrating radar line (fig. 3). See inset map for site location. IL - Illinois, IN - Indiana, MI - Michigan. 


\section{METHODS}

We collected 31 vibracores across 22 ridges in the Wentworth Woods Nature Preserve (WWW) following three roughly south- to north-oriented transects. For each of the 22 ridges, a vibracore was collected at the northern toeslope of each ridge using $7.65-\mathrm{cm}$ aluminum tubing to recover basal foreshore (swash zone) deposits that are a proxy for the elevation of the lake when each ridge formed (c.f. Thompson, 1992). For five of the ridges $(1805,1810,1813,1814$, and 1818) an additional toeslope vibracore was collected to evaluate the reproducibility of the basal foreshore elevation and to collect samples for optically stimulated luminescence (OSL) age control. The crests of four ridges $(1805,1810,1813$, and 1818) were also vibracored to retrieve samples for OSL age determination.

An optical transit was used to topographically survey the elevation of each core site, and data were referenced to the International Great Lakes Datum of 1985 (IGLD85). Crest and swale elevations were also surveyed to represent topographic changes that occur along the transects for facies and age reconstructions. Core locations were determined by averaging 100 measurements using a handheld global positioning system.

All the vibracores were returned to the laboratory at the Indiana Geological and Water Survey to be split open lengthwise, described, sampled, and photographed. Latex peels were made of the cores to preserve the core and enhance the ability to observe sedimentary structures. The crest vibracores and some of the toeslope vibracores were opened in controlled light so that OSL samples could be retrieved and then described under full light conditions. Samples retrieved for grain-size determination were processed using a Malvern Mastersizer 3000 laser particle-size analyzer, supplemented with sieving for particles greater than $1.4 \mathrm{~mm}$ in diameter. Core descriptions, peels, and grain-size analyses were used to establish the contact between the base of the foreshore and top of the upper shoreface deposits.

Soil pits were dug upslope from the toeslope vibracore sites on four ridges $(1805,1810,1813,1818)$. Samples for OSL age-determination were collected from these pits in $7.65-\mathrm{cm}$ diameter by $15-\mathrm{cm}$-long aluminum tubes that were hand-driven with a rubber mallet into the wall or floor of the pit, removed, and capped in the field. Sample collection followed standard field practice, specifically focussing on the C-horizon to avoid the bioturbation and pedogenesis and targeting depths and sediments that could be identified as either dune or foreshore facies. These samples were sent to the Optical Dating and Dosimetry Lab at North Dakota State University for analysis. Additional OSL samples retrieved from vibracores $(1801,1805 \mathrm{C}, 1810 \mathrm{~B}, 1810 \mathrm{C}$, 1813C, 1814B, 1818B, 1818C, and 1822) were collected to examine the viability of using vibracores for OSL age determinations as opposed to samples collected from soil pits. Processing of all OSL samples are ongoing and those results are not discussed in this paper.

Ground penetrating radar data were collected along the easternmost transect using a $250-\mathrm{MHz}$ Sensors and Software Noggin cart in common-offset mode with a trace collected every $5 \mathrm{~cm}$ (triggered by an odometer wheel) and a stacking of eight traces at each location. Elevations along this transect were collected at $1-\mathrm{m}$ intervals using an optical transit, similar to the methodology used to collect elevation data for vibracores, referenced to IGLD85. A cross section was created using Sensors and Software's EKKO Project (v. 5) using the LineView module. The data was processed for minor odometer wheel skipping, corrected for variations in topography, and displayed using a Dewow filter, an automatic gain control amplification with migration, and a sediment velocity of $0.15 \mathrm{~m} / \mathrm{ns}$.

\section{RESULTS}

Vibracores penetrated through eolian and foreshore deposits into upper shoreface sediments in 18 of the 22 cores. The other cores stopped in the slightly coarser, lower part of the foreshore facies. The two most landward cores (1801 and 1802) ended in the Wadsworth Till Member of the Wedron Formation. Dune sediments primarily comprise well- to moderately sorted, lower medium to upper very fine grained quartz-rich sand with rootlets and root mottles. Some faint low-angle parallel laminations defined by grain size and heavy minerals occasionally occurred in basal dune deposits. The contact with underlying foreshore sediment is not well defined and commonly gradational. Foreshore deposits are highly variable but typically coarsen downward from upper medium-grained to upper very fine grained quartz sand to upper very coarse grained, granular, and rare pebbly quartz sand. Pebbles consists of sandstone, siltstone, shale, and rip-up clasts of unconsolidated mud. Overall, foreshore deposits fine lakeward within the strandplain. Horizontal and subhorizontal parallel laminations and low-angle lakeward-dipping parallel laminations are most common, but some high-angle landward and lakeward-dipping parallel laminations can occur near the top and base of the unit. Laminations are defined by alternations in grain size, heavy minerals, and organics. Rare inversely graded parallel laminations were observed. The basal foreshore contact is sharp and defined by a distinct shift to finer-grained sediments in the upper shoreface facies. Unlike the foreshore, the upper shoreface deposits 
fine downward from lower medium to upper very fine grained quartz sand to lower fine to lower very fine grained quartz sand with silt and clay laminae and beds. Horizontal and discontinuous horizontal parallel laminations are common with ripples and micro-trough cross-stratification, scattered granules, pebbles, mud chips, and conispiral gastropods. Laminae are defined by grain-size changes and organics.

A graph of basal foreshore contact elevations with distance landward from ridge 1801 to 1815 shows little change in elevation, with all data points ranging between 182.5 and $182.8 \mathrm{~m}$ (IGLD85) (fig. 2). There is a slight rise in elevation to ridge 1816 where the

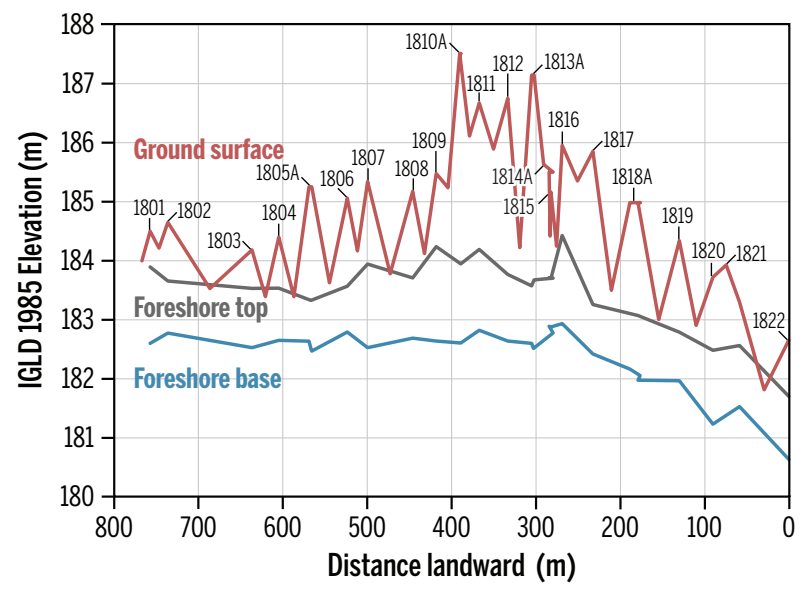

Figure 2. Line graph of foreshore contacts and ground surface elevations versus distance landward from the most lakeward ridge (1822). Basal foreshore elevations are a close approximation to the elevation of the lake when the beach ridge formed. The elevations are only relative to the Wentworth Woods area because of glacial isostatic warping of the basin after the ridges formed. The raw data for this graph is in Table 1. maximum basal foreshore contact elevation at WWW is $182.91 \mathrm{~m}$ (IGLD85). Following this peak in elevation, basal foreshore contact elevations fall approximately $2.2 \mathrm{~m}$ between ridges 1816 and 1822 . This relatively horizontal pattern of basal foreshore contact elevations followed by a fall in elevations towards the modern lake is very different from other sites in the less rebounded parts of the upper Great Lakes, where a pronounced rise in basal foreshore elevations occurs that lead up to the peak Nipissing (Thompson and others, 2011, 2014).

Assuming ridge 1816 represents the peak Nipissing for the Chicago outlet, the peak Nipissing elevation at WWW is $0.38 \mathrm{~m}$ lower than the peak Nipissing elevation at the Port Huron outlet (Thompson and others, 2011), suggesting a GIA rate between the two outlets of $0.8 \mathrm{~cm} /$ century $(0.38 \mathrm{~m} / 45$ centuries $)$. Modern lakelevel gauge data indicates a current rate of approximately $10 \mathrm{~cm} /$ century is occurring between the two sites (Mainville and Craymer, 2005). Continued analysis awaits the completion of the OSL age determinations and the development of an age model for the study area.

The GPR transect shows the typical pattern recognized by Johnston and others (2007). This pattern constitutes a series of lakeward-dipping sigmoidal-shaped reflections separated by concave upward ravinement-surface reflections (fig. 3). The surfaces represent the progression of various shoreline behaviors that include erosional regression, depositional regression, aggradation, and progradation that shorelines undergo during a general lakeward translation influenced by decadal lake-level change (Johnston and others, 2007; Thompson and others, 2011).

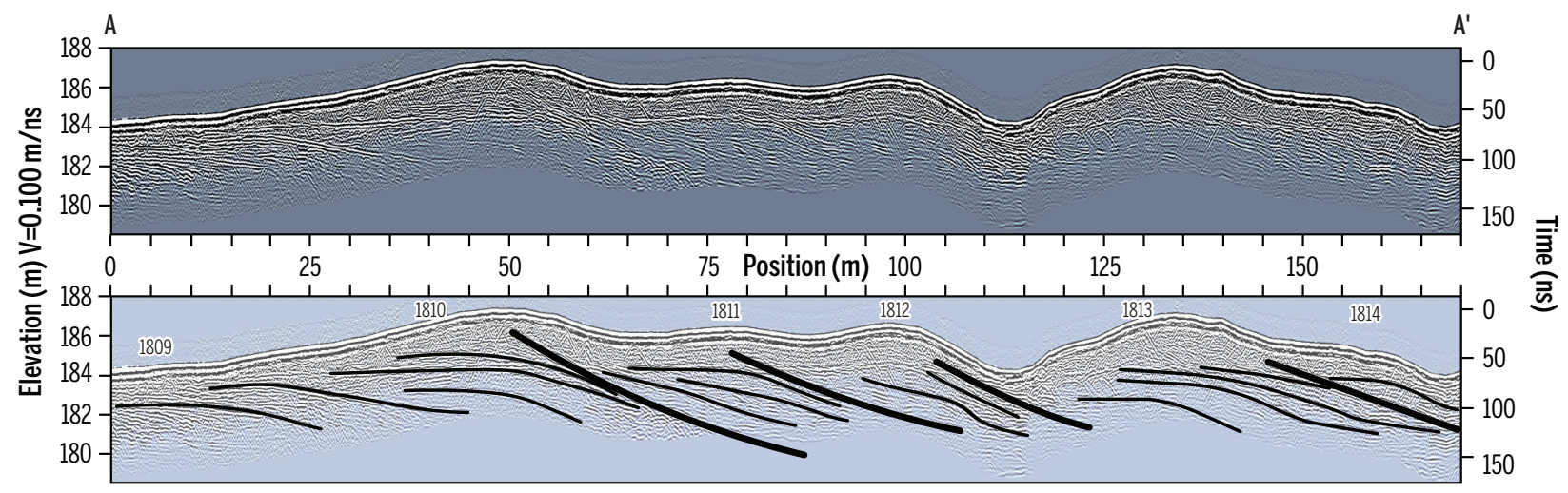

Figure 3. Images of the ground penetrating radar data collected along the easternmost vibracoring transect, crossing ridge 1809 to ridge 1814 . The upper image illustrates the processed data, and the lower diagram shows the interpreted transect. In the interpreted diagram, the bold concave upward lines represent ravinement surfaces, whereas the sigmoidal-shaped lines represent some lakeward translations of the shoreface. 
Table 1. Data obtained from vibracore description and surveying. These include land surface elevation, location of core sites, and elevation of the top and base of foreshore deposits. See Figure 1 for core location and number and Figure 2 for a graphical version of these data.

\begin{tabular}{|c|c|c|c|c|c|c|c|}
\hline $\begin{array}{l}\text { Core } \\
\text { Number }\end{array}$ & $\begin{array}{l}\text { Ridge } \\
\text { Number }\end{array}$ & $\begin{array}{c}\text { Land } \\
\text { Surface } \\
\text { (m IGLD85) }\end{array}$ & $\begin{array}{c}\text { UTM } \\
\text { Northing }\end{array}$ & $\begin{array}{c}\text { UTM } \\
\text { Easting }\end{array}$ & $\begin{array}{l}\text { Distance } \\
\text { (m) }\end{array}$ & $\begin{array}{c}\text { Foreshore } \\
\text { Top Elev. } \\
\text { (m IGLD85) }\end{array}$ & $\begin{array}{l}\text { Foreshore } \\
\text { Base Elev. } \\
\text { (m IGLD85) }\end{array}$ \\
\hline 1801 & 1 & 184.29 & 4605215.9 & 455661.8 & 230.79 & 183.89 & 182.60 \\
\hline 1802 & 2 & 184.11 & 4605227.0 & 455688.3 & 224.40 & 183.65 & 182.77 \\
\hline 1803 & 3 & 183.71 & 4605216.5 & 455956.9 & 194.01 & 183.53 & 182.52 \\
\hline 1804 & 4 & 183.72 & 4605248.0 & 455964.3 & 184.32 & 183.53 & 182.65 \\
\hline $1805 \mathrm{~A}$ & 5 & 184.23 & 4605287.8 & 455970.8 & 172.41 & 183.68 & 182.47 \\
\hline 1805B & 5 & 184.24 & 4605286.6 & 455971.2 & 172.69 & 183.33 & 182.50 \\
\hline $1805 C$ & 5 & 184.92 & 4605284.9 & 455969.4 & 173.41 & 184.28 & 182.63 \\
\hline 1806 & 6 & 184.39 & 4605330.7 & 455978.2 & 159.57 & 183.57 & 182.79 \\
\hline 1807 & 7 & 184.32 & 4605352.0 & 455989.5 & 152.22 & 183.94 & 182.52 \\
\hline 1808 & 8 & 184.19 & 4605404.4 & 456003.2 & 135.94 & 183.71 & 182.68 \\
\hline 1809 & 9 & 185.46 & 4605452.3 & 455964.6 & 127.41 & 184.24 & 182.91 \\
\hline $1810 \mathrm{~A}$ & 10 & 186.26 & 4605484.4 & 455960.8 & 118.92 & 184.19 & 186.26 \\
\hline 1810B & 10 & 186.26 & 4605485.6 & 455961.2 & 118.53 & 183.94 & 182.60 \\
\hline $1810 \mathrm{C}$ & 10 & 187.15 & 4605485.0 & 455959.5 & 118.92 & 185.07 & 187.15 \\
\hline 1811 & 11 & 185.99 & 4605502.8 & 455976.6 & 111.85 & 184.19 & 182.82 \\
\hline 1812 & 12 & 184.31 & 4605539.1 & 455978.1 & 101.55 & 183.76 & 182.64 \\
\hline $1813 \mathrm{~A}$ & 13 & 185.81 & 4605567.6 & 455990.8 & 92.03 & 183.67 & 0.00 \\
\hline 1813B & 13 & 185.77 & 4605567.7 & 455989.0 & 92.25 & 183.85 & 182.51 \\
\hline $1813 C$ & 13 & 186.19 & 4605561.6 & 455997.0 & 92.93 & 183.57 & 182.60 \\
\hline $1814 \mathrm{~A}$ & 14 & 184.07 & 4605584.9 & 455995.8 & 86.61 & 183.71 & 182.89 \\
\hline 1814B & 14 & 184.10 & 4605589.0 & 455998.1 & 85.17 & 183.70 & 182.77 \\
\hline 1815 & 15 & 184.28 & 4605700.2 & 455742.6 & 83.84 & 183.70 & 182.87 \\
\hline 1816 & 16 & 185.49 & 4605713.9 & 455744.5 & 81.89 & 184.43 & 182.93 \\
\hline 1817 & 17 & 183.86 & 4605745.3 & 455763.5 & 70.79 & 183.25 & 182.42 \\
\hline $1818 \mathrm{~A}$ & 18 & 183.40 & 4605802.5 & 455766.5 & 54.50 & 183.07 & 181.97 \\
\hline 1818B & 18 & 183.47 & 4605805.5 & 455766.1 & 53.72 & 182.77 & 182.05 \\
\hline $1818 \mathrm{C}$ & 18 & 184.90 & 4605793.0 & 455764.2 & 57.43 & 183.62 & 182.10 \\
\hline 1819 & 19 & 183.30 & 4605834.3 & 455815.4 & 39.56 & 182.79 & 181.96 \\
\hline 1820 & 20 & 183.42 & 4605877.2 & 455817.0 & 27.42 & 182.48 & 181.59 \\
\hline 1821 & 21 & 182.83 & 4605922.6 & 455792.7 & 17.80 & 182.56 & 181.52 \\
\hline 1822 & 22 & 181.97 & 4605988.2 & 455789.1 & 0.00 & 181.70 & 180.63 \\
\hline
\end{tabular}




\section{CONCLUSIONS}

Thirty-one vibracores were collected along three roughly south- to north-oriented transects in the eastern part of the Wentworth Wood Nature Preserve. Foreshore sediment contact elevations were determined from core descriptions and latex peels. The basal foreshore contact elevations are proxy for the relative elevation of the lake when each ridge formed. They show a long-term stable elevation until ridge 1816, where basal foreshore elevations reach a maximum elevation of $182.91 \mathrm{~m}$ and then decrease more than $2 \mathrm{~m}$ to ridge 1822. Ground penetrating radar data collected along the transect shows the punctuated nature of strandplain development caused by shorter-term fluctuations during the long-term pattern of lake-level change.

\section{ACKNOWLEDGMENTS}

We would like to thank the Cook County Forest Preserve for access to the study area. Students from Indiana University Northwest Department of Geosciences and Indiana University Bloomington School of Public and Environmental Affairs helped with the collected of vibracores, OSL samples, GPR, and topographic data. They are Steven Barajas, Cesar Garcia, Rachel Humes, Sam Rice, and Quintin Thompson.

\section{REFERENCES}

Johnston, J. W., Thompson, T. A., and Baedke, S. J., 2007, Systematic pattern of beach-ridge development and preservation-conceptual model and evidence from ground penetrating radar, in Baker, G. S., and Jol, H. M., eds., Stratigraphic analyses using GPR: Geological Society of America Special Paper 432, p. 47-58. doi:10.1130/2007.2432(04)

Mainville, A., and Craymer, M. R., 2005, Present-day tilting of the Great Lakes region based on water level gages: Geological Society of America Bulletin, v. 117, p. 1,070-1,080. doi:10.1130/B25392.1

Thompson, T. A., 1992, Beach-ridge development and lake-level variation in southern Lake Michigan, in Donoghue, J. F., Davis, R. A., Fletcher, C. H., and Suter, J. R., Quaternary coastal evolution: Sedimentary Geology, v. 80, p. 305-318. doi:10.1016/0037-0738(92)90048-V

Thompson, T. A., and Baedke, S. J., 1997, Strandplain evidence for late Holocene lake-level variations in Lake Michigan: Geological Society of America Bulletin, v. 109, p. 666-682. doi:10.1130/0016-7606(1997)109<0666:SPEFLH>2.3.CO;2

Thompson, T. A., Lepper, K., Endres, A. L., Johnston, J. W., Baedke, S. J., Argyilan, E. P., Booth, R. K., and Wilcox, D. A., 2011, Mid Holocene lake level and shoreline behavior during the Nipissing phase of the upper Great Lakes at Alpena, Michigan, USA: Journal of Great Lakes Research, v. 37, p. 567-576. doi:10.1016/j.jglr.2011.05.012

Thompson, T. A., Johnston, J. W., and Lepper, K., 2014, The contemporary elevation of the peak Nipissing phase at outlets of the upper Great Lakes: Geological Society of America Special Paper 508, p. 15-29. doi:10.1130/2014.2508(02) 